Estudios Constitucionales, Año 12, No 1, 2014, pp. 365-396.

ISSN 07180195

Centro de Estudios Constitucionales de Chile Universidad de Talca

"Auto-restricción, deferencia y margen de apreciación. Breve análisis de sus orígenes y de su desarrollo" José Ignacio Martínez Estay

\title{
AUTO-RESTRICCIÓN, DEFERENCIA Y MARGEN DE APRECIACIÓN. BREVE ANÁLISIS DE SUS ORÍGENES Y DE SU DESARROLLO*
}

\author{
SELF-RESTRAINT, DEFERENCE AND MARGIN \\ OF APPRECIATION
}

\author{
José Ignacio Martínez Estay** \\ Universidad de los Andes - Chile \\ jimartinez@uandes.cl
}

RESUMEN: El objetivo de este estudio es efectuar un breve repaso a los origenes y desarrollo de los principios de auto-restricción, deferencia y margen de apreciación, tanto en el ámbito del Derecho Constitucional como del Derecho Internacional, en especial el Derecho Internacional de los Derechos Humanos. Junto con analizar la relación entre jueces y control del poder, y el límite que para aquéllos supone el principio de separación de poderes, se revisará enseguida el significado de estos principios y la forma en que han sido acogidos en Inglaterra, Estados Unidos, Alemania y Francia, y en el ámbito de tribunales internacionales de derechos humanos y de integración supranacional. Finalmente se efectúa una breve referencia al concepto de auto-restricción, deferencia razonada y margen de apreciación en el Tribunal Constitucional chileno.

ABSTRACT: The aim of this paper is to make a brief review of the origins and development of the principles of self-restraint, deference and margin of appreciation, both in the field of Constitutional Law and International Law, particularly the International Law of Human Rights. Along with analyzing the relationship between judges and the control of power, and the separation of powers as a limit for the judicial review, will be revised the meaning of these principles and how they have been received in England, the USA, Germany and France, as well as in the field of international human rights courts and supranational integration courts. Finally the article contains a brief reference to the concept of self-restraint, reasoned deference and margin of appreciation in the Chilean Constitutional Court.

PALABRAS CLAVE: Auto-restricción, Deferencia, Margen de apreciación.

KEY WORDS: Self-restraint, Deference and margin of appreciation.

\footnotetext{
* El presente trabajo es parte de la investigación que está llevando a cabo el autor en el proyecto Fondecyt No 1120634, "Auto-restricción y deferencia razonada: Límites al escrutinio de la actividad legislativa, administrativa y judicial en el Tribunal Constitucional chileno". Trabajo recibido el 19 de marzo de 2013 y aprobado el 22 de enero de 2014.

** Profesor de Derecho Constitucional y Administrativo, Facultad de Derecho, Universidad de los Andes, Chile.
} 


\section{Presentación}

El control del poder y la garantía y protección de los derechos humanos es el objetivo primordial del Derecho Público. El Derecho Constitucional nació con tal objetivo, y el Derecho Internacional de los Derechos Humanos se ha desarrollado desde mediados del siglo XX con ese preciso fin. En ambos casos el rol de los jueces resulta trascendental. Tanto los jueces constitucionales como los jueces de tribunales internacionales de derechos humanos o de entidades supranacionales de integración deben llevar a cabo la difícil labor de controlar el poder del Estado, $y$, en su caso, brindar efectiva tutela a los derechos de las personas.

Una de las dificultades que conlleva esa actividad judicial es el riesgo de que los jueces se extralimiten en sus funciones y se involucren en materias que escapan a su competencia, ya sea violando el principio de separación de poderes (jueces constitucionales) o los legítimos ámbitos decisionales de los Estados (jueces de tribunales internacionales de derechos humanos o de tribunales de entidades supranacionales de integración). De ahí la trascendencia de contar con mecanismos que permitan eliminar o disminuir aquel riesgo, que es precisamente lo que persiguen los principios de auto-restricción, deferencia y de margen de apreciación.

El objetivo de este trabajo es efectuar un breve repaso a los orígenes y desarrollo de dichos principios, tanto en el ámbito del Derecho Constitucional como del Derecho Internacional, en especial el Derecho Internacional de los Derechos Humanos. Para tal efecto se recordará la razón por la cual existe una estrecha relación entre jueces y control del poder, y el límite que para aquéllos supone el principio de separación de poderes. En esta parte se aprovechará de exponer con brevedad el estado de la cuestión en Estados Unidos y Alemania, cuyos máximos órganos jurisdiccionales (Corte Suprema y Tribunal Constitucional, respectivamente) representan los dos modelos más relevantes de justicia constitucional.

A continuación se analizará el significado de estos principios, y la forma en que han sido acogidos en Inglaterra, Estados Unidos, Alemania y Francia. Asimismo, se revisará cómo han llegado a ocupar un destacado lugar en el ejercicio de las competencias de tribunales internacionales de derechos humanos (Corte Europea de Derechos Humanos y Corte Interamericana de Derechos Humanos) y de entes de integración supranacional (Tribunal de Justicia de la Unión Europea).

Este trabajo es un primer resultado del proyecto Fondecyt No 1120634, titulado "Auto restricción y deferencia razonada: Límites al escrutinio de la actividad legislativa, administrativa y judicial en el Tribunal Constitucional chileno". En posteriores trabajos se espera revisar la forma en que estos principios han recogi- 
dos por nuestro Tribunal Constitucional en el ejercicio de sus competencias de control del legislador, de la Administración y de los jueces.

\section{El CONTROL JUDiCIAL DE LAS ACTUACIONES DE LOS PODERES PÚBliCOS}

El Imperio del Derecho o Estado de Derecho implica la idea de que todos los poderes públicos deben someterse al Derecho y la necesidad de contar con mecanismos de control judicial de las actuaciones estatales. Como señala Aragón, "la Constitución no podría (...) 'ser' sin el control jurídico que es, por esencia, el control jurisdiccional" 1 . Así, desde el nacimiento del constitucionalismo se asignó al juez un rol esencial en estas materias, primero en Inglaterra y más tarde en EE.UU., a partir de Marbury v. Madison. En palabras de Wheare, "es función de los jueces decidir lo que el derecho es en casos de litigio. Una Constitución es parte del derecho y, por lo tanto, cae dentro de la competencia de los jueces. Por otro lado puede ocurrir que algún conflicto surja entre el derecho de la Constitución y alguna norma legal o alguna acción, sea del poder legislativo o del Poder Ejecutivo. En este caso, si han de decidir lo que el derecho es, los jueces deben definir no sólo el significado de la ley ordinaria sino también el del derecho de la Constitución"2.

En un comienzo, en la tradición europea continental el papel del juez en materia constitucional era prácticamente inexistente ${ }^{3}$. El tiempo se encargó de demostrar que el éxito del modelo constitucional anglosajón se basaba en parte en el importante lugar que ocupan aquéllos. Por eso esta visión "cambia radicalmente con las constituciones rígidas de la segunda posguerra (...) que completan el paradigma del Estado de derecho al someter también al legislador a la ley -a la ley constitucional, más precisamente- transformando así el viejo Estado de derecho en Estado constitucional de derecho". En este nuevo escenario "la sujeción a la ley y antes que nada a la constitución transforma al juez en garante de los derechos fundamentales, incluso frente al legislador" ${ }^{4}$. Si bien se siguió manteniendo una cierta desconfianza en los jueces ordinarios, la experiencia demostró la necesidad de contar con órganos jurisdiccionales especializados en materia constitucional,

\footnotetext{
${ }^{1}$ Aragón (1999), p. 106.

2 WheAre (1975), p. 105.

3 Ibid., 107-109; Pereira (2006), pp. 199-204.

${ }^{4}$ Ferrajoli (2008), pp. 209 y 211.
} 
los Tribunales Constitucionales, dotados de la facultad de controlar los actos del legislador e incluso los del Ejecutivo5.

\section{CONTROL JUDICIAL Y SEPARACIÓN DE PODERES}

Como se sabe, uno de los pilares del constitucionalismo es el principio de separación de poderes. En palabras de Montesquieu ${ }^{6}$, implica la idea de que el poder frene al poder. Madison advertía que la clave de este principio radicaba no sólo en la necesidad de reconocer que "los poderes propios de uno de los departamentos no deben ser administrados completa ni directamente por cualquiera de los otros". Además era necesario "establecer medidas prácticas para que cada uno pueda defenderse contra las extralimitaciones de los otros"7.

El problema es que el propio constitucionalismo supone también la necesidad de que uno de esos poderes, el Judicial, controle que los otros dos ajusten su actuar a la Constitución. Como señalaba Hamilton, los jueces deben velar por que el legislador actúe de acuerdo a "los límites asignados a su autoridad". Si hay una incompatibilidad entre los actos "de una autoridad superior y otra subordinada, de un poder original y otro derivado", debe preferirse el primero respecto del segundo ${ }^{8}$.

Pero ¿cuál es el límite del control judicial de los actos de los poderes públicos y evitar así transformar a los jueces en un súper poder? A este respecto Loewenstein sostiene que existen dos áreas en donde el control judicial no merece reparos:

1. En los sistemas federales "es indispensable un órgano para ajustar los conflictos entre el Estado central y los Estados miembros (...) Consecuentemente, las relaciones entre el Estado central y los Estados miembros es el dominio legítimo del control judicial"?.

2. En "la protección de las libertades civiles y de los derechos fundamentales que ostentan de igual forma todos los destinatarios del poder". En este caso "la actividad de los jueces consiste (...) fundamentalmente, sólo en la aplicación de aquellas normas que protegen las libertades civiles contra las intervenciones de la legislación y de la administración"10.

5 Loewenstein (1976), pp. 304-305.

${ }^{6}$ Montesquieu (1998), Libro XI, Cap. 5.

7 Hamilton, A.; Madison, J., y Jay, J. (1943), p. 210.

8 Ibid., pp. 332, 333.

${ }^{9}$ Loewenstein (1976), p. 311.

${ }^{10} \mathrm{Ibid}$. 
Sin embargo, Loewenstein precisa que a veces los jueces deben "enfrentarse con cuestiones entrañando la determinación de las decisiones políticas". Así ocurrió con las sentencias de la CS norteamericana, que declararon inconstitucional la segregación racial en las escuelas ${ }^{11}$. Pero hay un ámbito que según Loewenstein debe estar absolutamente vedado a los jueces: “(...) cuando los jueces proclaman su derecho de valorar una decisión político-social y político-económica de los detentadores del poder -gobierno y parlamento-" 12 . No obstante, el propio Loewenstein advierte que siempre será posible "camuflar" esta interferencia judicial bajo la premisa de defensa de la supremacía constitucional, transformándose el Poder Judicial en "árbitro soberano sobre el Congreso y el presidente, aunque ambos están elegidos por el pueblo y están obligados a rendir cuentas a los electores"13. En resumen, "si el control judicial se aplica a decisiones políticas, adquiere entonces el carácter de un control político por parte de los tribunales que, teóricamente, no corresponde a la función judicial"14.

Por su parte, Ferrajoli sostiene que la garantía de los derechos y el control de juridicidad de los actos de los poderes públicos son competencias propias de la jurisdicción, por lo que carece de sentido de hablar de politización de la justicia. Esto porque ella sólo puede intervenir sobre aquello que no es propio de la política, "sobre los actos inválidos y los actos ilícitos"15.

Pero la tarea no es fácil, como se constata tanto en las tradiciones angloamericana y europea continental. En el caso de la primera es bastante decidor lo que ocurre, por ejemplo, en Estados Unidos, en donde hay quienes sostienen que el common law exige que los jueces apliquen sus convicciones morales en sus decisiones, lo que constituiría "una contribución esencial al desarrollo del common law" 16. Esta es además la posición de destacados miembros de la Corte Suprema norteamericana como los justices Cardozo y Brennan, aunque el juez Bork entiende que donde la Constitución no se aplica, el juez "debe adoptar una postura de abstención moral" 17 . Se trata de una temática de amplio debate hoy en Estados

\footnotetext{
11 Ibid.

12 Ibid., p. 312.

13 Ibid.

${ }^{14}$ Ibid.

15 Ferrajoli (2008), p. 215.

16 Por ejemplo, Eduin (2010), 124 (la traducción es mía).

17 Ibid.
} 
Unidos, ya que desde el conocido caso Marbury v. Madison hasta la fecha, la Corte Suprema ha ido adoptando una actitud activista, que muchos ven no sólo con recelo, sino además como una abierta intromisión en las competencias de los otros poderes, en especial del Congreso. Más aún, algunos sostienen que ello es contrario a un principio básico del constitucionalismo como lo es que nadie puede monopolizar el Derecho, lo que en palabras de Stith implica la existencia de un pluralismo jurídico ${ }^{18}$. Y otros señalan que simplemente el judicial review es contrario a la Constitución norteamericana, porque nunca estuvo contemplado por ésta ${ }^{19}$.

Por su parte, en la tradición europeo-continental la proliferación de tribunales constitucionales ha llevado a que "el mito cuasi-oficial de los jueces como esclavos de los códigos, que tienen prohibido realizar una interpretación creativa que lleve a la reescritura de las leyes, se ha hecho añicos" 20 . Y es que, como lo demuestra el caso alemán, los tribunales constitucionales han pasado a ser actores determinantes no sólo de la vida jurídica, sino que además política del país. En tal sentido, la ex jueza del Tribunal Constitucional de Alemania, Evelyn Haas, ha señalado que "la juridificación de la política, la necesidad de circunscribir normativamente la acción política, deriva obligadamente en su judicialización. Los proyectos políticos del gobierno legitimado democráticamente son justiciables y entregados al control jurídico de los jueces del Tribunal Constitucional Federal (TCF)"21. En su opinión, el rol de "custodio de la Constitución" que le asignaron los constituyentes alemanes "le permite a éste una participación decisiva en la conducción política del Estado. Quien ostenta el control sobre la Constitución, que es derecho político, ejerce un alto grado de poder político"22.

Junto a ella otros destacados jueces del Tribunal Constitucional han manifestado su opinión a este respecto, las que han sido muy bien resumidas por Kommers. Así, hay quienes, como Leibholz, entienden que es indispensable distinguir entre

18 STith (2005), pp. 157-182 y (2008), pp. 401-447. Ver también MarTinez (2009), pp. 357-358.

${ }^{19} \mathrm{Al}$ respecto resulta recomendable la lectura de GOLDSTONE (2008).

20 STONE (2000), 115. El debate se ha dado también en el Reino Unido, sobre todo a partir de la aprobación de la Human Rights Act de 1998, que ha relativizado el viejo principio de "soberanía del Parlamento", vigente desde el siglo XVII. Ello ha supuesto una nueva forma de ejercer el judicial review, que hasta ese momento sólo se ejercía para el control de los actos de la Administración, ampliando su aplicación al control de los actos del Parlamento. Las implicancias de esto y diversas posiciones frente a las consecuencias de la Human Rigths Act pueden consultarse en FORSYTH (2000).

${ }^{21}$ HaAs (2010), p. 367.

22 Ibid., p. 368. 
litigios político-jurídicos de aquéllos meramente políticos. En estos últimos el Tribunal carece de competencia. Pero agrega que "sería una ilusión y un positivismo inadmisible suponer que es posible o que está autorizada la aplicación de los principios constitucionales generales, sin al mismo tiempo tratar de ponerlos en una relación razonable con el orden político dado. El juez constitucional no puede hacer otra cosa que aplicar las normas a la realidad política".

Otros, como Hesse, sostienen que la interpretación constitucional es producto de la reflexión que hace el juez acerca del significado de una norma de la Constitución tomando en consideración el lenguaje constitucional y el contexto histórico. Por su parte, Böckenförde entiende que la interpretación requiere tomar en consideración las teorías políticas acerca "del Estado liberal, del Estado social y del Estado democrático". A su vez, Grimm piensa que "los tribunales constitucionales cruzan inevitablemente la línea entre el Derecho y la Política”, lo que hace necesario apuntar a menos control judicial en la vida política y legislativa. Por último, otros jueces entienden que el control e interpretación constitucional es un "trabajo dialéctico: la respuesta correcta en un caso dado es el producto de una decisión adoptada de manera colectiva; una decisión correcta o buena es aquella que ha desterrado el desacuerdo en el disolvente de la discusión en grupo y el diálogo"23.

En cualquier caso, es innegable el trascendental rol que ha llegado a jugar el Tribunal Constitucional alemán a través del control de constitucionalidad de los actos de los poderes públicos, al punto que "ostenta una posición importante en la vida política de Alemania, siendo acusado a veces de ser un gobierno paralelo e incluso de contrapoder" 24 .

En resumen, si bien no parece posible concebir un sistema constitucional sin control judicial de la actuación de los poderes públicos, lo cierto es que no resulta fácil delimitar con claridad el ámbito en el cual los jueces constitucionales deben ejercer sus funciones. Más aún, el peligro del activismo judicial es un riesgo latente, que puede llevarlos a inmiscuirse en ámbitos ajenos a ellos, y más bien propios de los poderes políticos, o incluso a incursionar y decidir sobre materias propias de

23 Kommers (1997), p. 44 (la traducción es nuestra).

${ }^{24}$ HaAs (2010), p. 367. Pero como apunta la propia Haas, ello no ha impedido que el Tribunal Constitucional alemán esté muy bien valorado por la opinión pública, p. 370. Asimismo, es importante considerar lo señalado por la autora en orden a que una de las razones por las que desde su nacimiento se ha ido incrementando el poder del Tribunal Constitucional, es "su tesis de que los derechos fundamentales representan un orden objetivo de valores", p. 372. 
la ciencia o de la moral. La clave está, entonces, en contar con mecanismos que ayuden a evitar o disminuir esos riesgos.

\section{LA AUTO-RESTRICCIÓN, LA DEFERENCIA RAZONADA \\ Y EL MARGEN DE APRECIACIÓN}

Como ya se dijo, el desafío del control judicial es cómo hacer para que éste no sirva para la intromisión de los jueces en materias que no son de su competencia. En otros términos, cómo evitar el activismo judicial o la sustitución de las decisiones meramente políticas por sentencias o en donde hay tribunales constitucionales, la intromisión de éstos en las competencias de los jueces de la instancia. Es en este marco en donde juega un rol importante el concepto de deferencia o de autorestricción que "encierra dos sentidos complementarios". Por una parte, implica "que los poderes públicos se deben una actitud remanente y recíproca de respeto y cortesía" y, por otra, supone "de cada órgano del Estado el reconocimiento y respeto de las esferas competenciales en que las autoridades tienen el derecho a tomar decisiones con relativa autonomía" 25 .

Y en lo que toca específicamente a las relaciones entre el legislador y los jueces constitucionales, la deferencia razonada o auto-restricción judicial implica:

-El reconocimiento de lo que acertadamente el propio Zapata denomina "autonomía del legislador". Esto significa que, dentro de los márgenes fijados por la Constitución, el legislador goza de libertad para el ejercicio de su función ${ }^{26}$. Esa libertad o autonomía "comprende, básicamente, el conjunto de apreciaciones de mérito y oportunidad que llevan al legislador a la adopción de una u otra fórmula normativa" 27.

-Para algunos supone, además, la presunción de constitucionalidad de los actos del legislador, posición sostenida, por ejemplo, por Zapata ${ }^{28}$.

Pero a su vez, y más o menos por las mismas razones, puede concluirse que las relaciones entre el Ejecutivo y los jueces constitucionales implican también:

25 ZapATA (2008), p. 227.

${ }^{26}$ Ibid., p. 233.

27 Ibid., p. 234.

28 Ibid., pp. 243 y ss. 
- El reconocimiento de un cierto margen de autonomía del Ejecutivo con relación a las funciones de gobierno y de administración, obviamente dentro de los márgenes contemplados en la Constitución.

- La presunción de legalidad y, en último término, de juridicidad de los actos administrativos, que al menos en Chile está expresamente prescrita en los artículos $3^{\circ}$ inciso 8 y 51 de la Ley No 19.880 sobre Procedimientos Administrativos, respectivamente ${ }^{29}$.

Hasta las reformas introducidas por la Ley No 20.050, la deferencia se había examinado principalmente en las relaciones entre el Tribunal Constitucional, la Administración (básicamente la Presidencia de la República) y el Parlamento. A partir de dicha reforma, la deferencia asume otra faceta en las relaciones con la judicatura, porque la inaplicabilidad -por la vía del llamado control "concreto"permite anticiparse a la decisión de controversias judiciales. Desde este punto de vista la deferencia en las relaciones entre los jueces ordinarios y especiales y el TC deben basarse en la autonomía de los primeros para interpretar y aplicar el Derecho en la resolución de los conflictos sometidos a ellos, pero actuando en estas materias "conforme a los normas constitucionales"30. Ello implica el debido cuidado que el Tribunal Constitucional debe tener a efectos de no sustituir la labor del juez ordinario ${ }^{31}$.

\section{LA AUTO-RESTRICCIÓN O DEFERENCIA EN EL DERECHO \\ CONSTITUCIONAL COMPARADO}

\section{Inglaterra}

Uno de los principios estructuradores del Derecho Constitucional inglés es la "soberanía del Parlamento", que surgió en la segunda mitad del siglo XVII, tras la derrota de las pretensiones absolutistas de los Estuardo ${ }^{32}$. Significa que "el Parlamento es soberano, considerado como legislador" 33 y, por ende, "toda ley válidamente aprobada por el Legislativo y que haya obtenido el Royal Assent será

\footnotetext{
29 Ello sin perjuicio de que un importante sector de la doctrina chilena pone en duda la constitucionalidad de estas normas. Vid. Soto Kloss (2012), p. 337.

30 Hormazábal (2006), p. 36.

31 Ver Aldunate (2009), pp. 11-12; también ZúNiga (2010), pp. 176-181.

32 Pereira (1992), pp. 119-121; 138-139.

33 Ibid., p. 135.
} 
aplicada por los jueces"34. Por ende, formalmente no hay espacio para el judicial review de la ley.

Pero los jueces sí controlan los actos administrativos, y es en este ámbito donde prima el principio de deference, que implica por una parte el reconocimiento de la autonomía de la Administración para adoptar actos administrativos, así como la reserva legal de sus competencias (caso Associated Provincial Picture Houses v. Wednesbury Corporation -Court of Appeal, England and Wales-, de 1948). No obstante se ha producido una evolución importante en la última década por la vía de la aplicación del principio de proporcionalidad. Ello ha supuesto una mayor intervención judicial, inspirado en el criterio de control de las cortes alemanas y de las europeas de Estrasburgo y Luxemburgo.

Asimismo, y como señaló antes, la promulgación de la Human Rights Act (1998) ha supuesto un cambio importante al permitir expresamente el judicial review de todas las actuaciones estatales que afectan derechos humanos. En la práctica ello implica la posibilidad de controlar los propios actos del legislador (poniendo en duda la soberanía del Parlamento) y de los actos administrativos desde un punto de vista sustantivo, así como el análisis jurisdiccional de la motivación fáctica, la interpretación administrativa de las leyes, el debido procedimiento y las medidas de protección otorgada. Sin embargo, aún subsisten interrogantes respecto del grado de intensidad con que debería ser aplicada en los distintos contextos normativos. En particular, la duda se refiere a los ámbitos de decisión que no afectan derechos fundamentales y otros en que la intervención judicial a través de la proporcionalidad podría extenderse indebidamente al control de mérito de los actos, vulnerando de paso el principio de soberanía del Parlamento en cuanto órgano superior de distribución de competencias ${ }^{35}$.

\section{Estados Unidos de Norteamérica}

Desde finales del siglo XIX hasta la década de los 30 del siglo XX, la Corte Suprema adoptó una actitud de intervencionismo en materias bastante lejanas a la función jurisdiccional, como lo es la defensa de un modelo económico absolutamente liberal. La Corte fundó su posición en el debido proceso y en la cláusula de comercio (art. 1.8) para impedir "la regulación gubernamental sobre la economía y la industria, evitando el acercamiento a la justicia social exigido por las mayorías

${ }^{34}$ Ibid., p. 249.

35 Estos aspectos están abordados en los diversos trabajos reunidos en FORSYTH (2000). 
progresistas en las asambleas legislativas federales y en las asambleas legislativas de los Estados miembros"36. La situación llegó a un punto crítico durante el gobierno del presidente Franklin D. Roosevelt y su política de New Deal, con la que pretendía afrontar los efectos de la gran depresión. La Corte Suprema declaró inconstitucionales varias medidas del plan, lo que condujo a una confrontación entre el alto Tribunal y el presidente Roosevelt, que terminó con una reforma a la composición de la Corte, que supuso un cambio de su posición respecto a las políticas del New Deal 37 .

Desde ese momento la Corte comenzó atenuar el ejercicio de su control aplicando tres criterios:

-En primer lugar, "la intervención de los tribunales se limita a aquellos 'casos’ y 'litigios' auténticos”. A diferencia de los dictámenes jurídicos y sentencias aplicadas in abstracto (control abstracto de normas).

-En segundo lugar, "rige el principio de que la voluntad del Congreso debe ser respetada siempre y cuando no viole directamente la Constitución, tal como es interpretada por la Supreme Court" 38 . Así, el legislador disfruta de "primacía legislativa", que se traduce en que el "control judicial, en su encarnación constitucional o de common law, no puede minar la autoridad legal o política de la legislatura", y que las cortes "reconocen que los actos del legislador, la mayoría de las veces, reflejan adecuadamente los intereses de la nación y de la mayoría de sus ciudadanos" 39 .

-En tercer lugar, "los tribunales (...) rehúsan tratar las llamadas 'cuestiones políticas' (political questions)" 40 . Douglas resume todo lo anterior señalando que el balance entre la primacía del legislador y el deber de ejercer control judicial radica en la idea de deferencia como respeto, "que exige que los jueces no anulen las leyes, a menos que (1) no haya ninguna formulación o interpretación de la ley que permitan salvar sus defectos y (2) que no haya otra base sobre la cual resolver el caso" ${ }^{41}$.

\footnotetext{
36 LoeWENSTEIN (1976), p. 312.

37 Varios autores (Sutherland (1972), pp. 583-609; Maltz (1994), p. 42; Kelly, Harbison, y Belz (1983), pp. 483-493; Wheare (1975), pp. 113-114; Loewenstein (1976), p. 312; Pereira (1998), p. 79).

38 Loewenstein (1976), p. 313.

39 EdLIN (2010), p. 157.

40 Loewenstein (1976), p. 313.

${ }^{41}$ Eduin (2010), p. 158.
} 


\section{Alemania}

Schneider destaca que el TC alemán "practica de hecho, desde el comienzo de su existencia y en formas muy diversas, la autolimitación judicial, limitando sus propias competencias de control sobre actos del Legislativo, del Gobierno y de los Tribunales con ayuda de distintos argumentos y teniendo en cuenta cada función estatal" 42 . En tal sentido, el TC alemán ha elaborado lo que podríamos denominar tres subprincipios, cada uno de ellos aplicable al legislador, al Ejecutivo y a los tribunales, respectivamente:

- El primero es el principio de libertad de configuración del legislador: “(...) dentro de los límites extremos (arbitrariedad, desproporcionalidad, abuso) no se produce ningún control de contenido de las decisiones legislativas por parte del Tribunal Constitucional, lo que ciertamente no impide un control de comportamiento o de procedimiento" ${ }^{43}$. Como agrega Zapata, el TC alemán sostiene que "no le corresponde imponer su visión respecto a la conveniencia o sabiduría de una determinada política pública adoptada por el Parlamento" ${ }^{44}$. Es importante destacar que el Tribunal ha relacionado este principio con el de proporcionalidad, porque implica un ámbito de apreciación de la idoneidad de ciertos medios para afrontar una determinada necesidad ${ }^{45}$.

- El segundo subprincipio es el de discrecionalidad del gobierno: Schneider destaca que esta discrecionalidad "se guía por consideraciones de racionalidad teleológica y de utilidad; no está sujeta a ningún tipo de control por parte del Tribunal Constitucional, mientras no se compruebe una violación evidente de la Constitución. Esto acontece especialmente cuando el Gobierno actúa contra un precepto expreso de la Constitución". Pero no son justiciables "los 'acontecimientos políticos', las cuestiones 'de alta significación política', 'las previsiones de una evolución política en el futuro' y, sobre todo, 'los pactos políticos”' 46 .

- Por último, el tercer subprincipio es el de interpretación del derecho ordinario: apunta a proteger la libertad de los tribunales para interpretar el derecho ordinario. El principio se traduce en la idea de que al Tribunal Constitucional sólo

\footnotetext{
42 SChNeIder (1991), p. 215.

43 Ibid.

44 ZaPATA (2008), p. 247.

45 Ibid.

46 SCHNEIDER (1991), p. 216.
} 
"le compete la reparación de 'una violación del Derecho constitucional específico"”, y no le corresponde "interpretar ni aplicar el derecho común como tal” 47.

El Tribunal ha elaborado una serie de parámetros que en teoría permiten determinar cuándo hay tal violación del Derecho constitucional específico:

- En casos de recursos de amparo constitucional con relación a acciones u omisiones al interior de un proceso, el Tribunal entiende que se afecta el Derecho Constitucional específico cuando "haya que recurrir contra la dirección del proceso (artículos 101.1 y 2; 103.1 de la Ley Fundamental) o contra el desconocimiento de la dimensión jurídico-procesal de los derechos fundamentales (por ejemplo, artículo 14)".

- En los casos sobre recurso de interpretación, hay afectación al Derecho constitucional específico "cuando el juez al interpretar el derecho ordinario ha sentado una premisa anticonstitucional" 48 .

Lo mismo se aplica al efectuar control del juicio de ponderación que haya efectuado un juez cuando aquél haya sido efectuado tomando en consideración una aplicación errada de la Constitución ${ }^{49}$. Es importante tener presente que el TC ha complementado el principio de deferencia y los subprincipios antes mencionados con una serie de variantes que adoptan sus sentencias, dependiendo el órgano afectado por el control y de la norma controlada.

- Con relación al legislador, el Tribunal utiliza muy acotadamente la declaración de nulidad de la ley por inconstitucionalidad. En tal sentido la regla es que sólo se declara la nulidad si ello permite "restablecer inmediatamente una situación de conformidad con la Constitución" 50 . Pero el principio general es que el Tribunal se limita a declarar la incompatibilidad o inconstitucionalidad "encomendando al Legislativo la nueva redacción", caso en el cual "sigue estando vigente la norma anticonstitucional -para evitar un vacío de regulación- hasta su inaplazable reelaboración" 51 . Ello se aplicará en los casos en que "la anticonstitucionalidad no es evidente o sobreviene con el transcurso del tiempo". En tal caso el Tribunal le encarga al legislador que formule una nueva redacción de acuerdo a las consideraciones señaladas en los considerandos del fallo. Asimismo, el Tri-

\footnotetext{
47 Ibid.

48 Ibid.

49 Ibid.

50 Ibid., pp. 218-219.

51 Ibid., p. 219.
} 
bunal dicta sentencias de aviso en las que "califica a una situación como 'todavía conforme con la Constitución', pero añade numerosas indicaciones sobre necesarias reglamentaciones para el futuro" 52 . Por último, el Tribunal utiliza también la técnica de la interpretación conforme con la Constitución, en el caso en que una ley puede ser considerada constitucional siempre que su aplicación se ajuste al criterio sentado en la sentencia ${ }^{53}$.

- Con relación al control de actos del Gobierno la regla general es que el Tribunal "se contenta (...) con una comprobación de la infracción constitucional, sin añadirle indicaciones complementarias para la eliminación de las consecuencias o para una actuación futura" 54 . Por su parte, cuando el control recae sobre tratados internacionales suscritos por el Gobierno, "la declaración de nulidad se sustituye las más de las veces por una declaración de no aplicabilidad como derecho interno", pero el Tribunal también puede aplicar la técnica de la interpretación conforme ${ }^{55}$.

- Con relación al control de actuaciones judiciales, las técnicas utilizadas por el Tribunal varían dependiendo de si se trata de un recurso de amparo o de un control concreto de normas. En el primer caso, el Tribunal comprueba la infracción, y si existe, "invalida la decisión del tribunal de instancia y se le devuelve por último el asunto" 56 (Ibíd., 221). Cuando hay control de normas se efectúa la declaración de nulidad y de inaplicabilidad, matizado todo ello por el uso de la interpretación conforme a la Constitución.

\section{Francia}

En Francia, el margen de apreciación ha sido utilizado como criterio por el Conseil d'Etat a propósito del control de la discrecionalidad administrativa o pouvoir discrétionnaire, en casos paradigmáticos como el arrêt Gomel (1914) o el más conocido arrêt Lagrange (1961) ${ }^{57}$. Este órgano ha calificado el control judicial como uno de naturaleza restreint, no obstante haya también lugar para el desarrollo de principios como el de proporcionalidad. Pero desde la década de

52 Ibid.

53 Ibid.

${ }^{54}$ Ibid.

55 Ibid.

56 Ibid., p. 221.

57 Vid. Laubadére, Venezia y Gaudemet (1990), pp. 538 y ss.; Rivero y Waline (1992), pp. 71 y ss. 
los 80 del siglo pasado, el margen de apreciación ha sido incorporado también como criterio de control de constitucionalidad por el Conseil Constitutionnel, al menos a partir de la decisión 86-218 DC, de 18 de noviembre de $1986^{58}$. En tal sentido, el margen de apreciación es un mecanismo que permite al Conseil determinar si la actuación del legislador se enmarca o no dentro de su legítima facultad de decisión política.

Para tal efecto, la intensidad del control que ejerce el Conseil transita entre un control mínimo, que denomina control del error manifiesto, y uno máximo, para el que aplica el principio de proporcionalidad. El primero es utilizado en aquellas materias en que el legislador cuenta con una mayor libertad, en atención a que la regulación constitucional es menos específica. Por el contrario, el control más intenso es ejercido respecto de aquellas materias en las que la Constitución le ha dejado menos espacio a la regulación legislativa ${ }^{59}$.

\section{LA DEFERENCIA Y EL MARGEN DE APRECIACIÓN EN LOS}

\section{SISTEMAS JURÍDICOS SUPRANACIONALES}

La deferencia hacia los Estados y el margen de apreciación nacional son principios de enorme relevancia en el ámbito de los sistemas jurídicos supranacionales. Su fundamento radica en el denominado principio de subsidiariedad, en virtud del cual se presume que los Estados están en mejor posición para determinar la forma más adecuada de ajustarse a sus compromisos jurídicos internacionales.

Una de las consecuencias más relevantes de estos principios es el hecho de que la actuación de los órganos jurisdiccionales supranacionales está sujeta a ciertas limitaciones en el ejercicio de sus funciones, en especial la interpretación de los tratados. Como señala Cançado Trindade, "los elementos que constituyen la regla general de interpretación de los tratados, formulada en el artículo 31(1) de las dos Convenciones de Viena sobre el Derecho de los Tratados - a saber, la buena fe, el texto, el contexto y el objeto y fin del tratado-, son los que con más frecuencia se hacen presentes en la interpretación de los tratados en la actualidad"60. Y si bien los tratados de derechos humanos, en atención a su naturaleza, están sujetos

\footnotetext{
58 La decisión puede consultarse en http://www.conseil-constitutionnel.fr/conseil-constitutionnel/francais/ les-decisions/acces-par-date/decisions-depuis-1959/1986/86-218-dc/decision-n-86-218-dc-du-18-novembre-1986.8291.html.

59 Sobre la intensidad del control de constitucionalidad por el Conseil Constitutionnel, ver FAVOREAU y PHILIP (1991), pp. 473 y ss. También Goesel-Le Bihan (2009).

60 CANÇADO (2001), p. 21.
} 
a una "interpretación propia"61 -que en el marco de la Convención Americana se manifiesta normativamente en su artículo $29^{62}$, " "no por eso se aparta de las reglas de derecho internacional generalmente reconocidas sobre la materia" 63 .

En este mismo sentido se pronuncian Jacobs y White, a propósito de la Convención Europea de Derechos Humanos, al señalar que el punto de partida de la labor interpretativa de la Corte Europea de Derechos Humanos y de la Comisión se encuentra "en las reglas generales de interpretación de los tratados" de los artículos 31 al 33 de la Convención de Viena ${ }^{64}$. Éstas incluyen, desde luego, el tenor de los términos usados en el respectivo tratado de derechos humanos.

Así, es evidente que en materia de tratados sobre derechos humanos el intérprete debe considerar muy especialmente el texto, es decir, su tenor. Como señala Núñez, "cabe recordar que la jurisprudencia internacional se encuentra limitada por el texto de un modo mucho más grave que el juez nacional. En efecto, si bien es cierto que a partir de los textos es posible defender una interpretación evolutiva, que adecue los textos "vivos [...] a la evolución de los tiempo y, en particular, a las condiciones de vida actuales", ello no significa un desprecio total por el método positivo en la interpretación de dichos instrumentos" 65 . Ello es de vital importancia, ya que no puede pasarse por alto el hecho de que los tratados internacionales son producto de negociaciones y acuerdos entre Estados, plasmados por escrito y traducidos por ende a palabras, a las que evidentemente éstos les han dado un sentido determinado. La buena fe internacional conlleva, por tanto, a que no pueda torcerse o desconocerse el significado de esas palabras ${ }^{66}$.

${ }^{61}$ Ibid., p. 26.

62 "Ninguna disposición de la presente Convención puede ser interpretada en el sentido de:

a) permitir a alguno de los Estados Parte, grupo o persona, suprimir el goce y ejercicio de los derechos y libertades reconocidos en la Convención o limitarlos en mayor medida que la prevista en ella.

b) limitar el goce y ejercicio de cualquier derecho o libertad que pueda estar reconocido de acuerdo con las leyes de cualesquiera de los Estados Parte o de acuerdo con otra convención en que sea parte uno de dichos Estados.

c) excluir otros derechos y garantías que son inherentes al ser humano o que se derivan de la forma democrática representativa de gobierno, y

d) excluir o limitar el efecto que puedan producir la Declaración Americana de Derechos y Deberes del Hombre y otros actos internacionales de la misma naturaleza”.

63 Ibid., p. 26.

${ }^{64}$ JACOBS et al. (1996), p. 26.

65 NúNEZ (2009), p. 513.

${ }^{66}$ NúNÉEZ sostiene a este respecto que "a diferencia de lo que puede suceder en el orden nacional, el silencio de los tratados refleja muchas veces la falta de consenso sobre lo universal. En este sentido, hay que reconocer 
Lo mismo ocurre en el ámbito de los sistemas jurídicos de integración, en los que los Estados cuentan con una cierta discrecionalidad a la hora de desarrollar algunas decisiones provenientes de órganos supranacionales. Así sucede, por ejemplo, en el ámbito de la Unión Europea, según se verá a continuación. No obstante, debe reconocerse que parte sustancial de los principios estructuradores del proceso de integración europeo son producto de la interpretación judicial y no emanan expresamente de los tratados constitutivos. Tal es el caso de los principios de supremacía ${ }^{67}$ y directa aplicabilidad del derecho comunitario ${ }^{68}$, y de otros que han sido recogidos por la jurisprudencia del Tribunal de Justicia de la UE, y son producto de su interpretación de los tratados. En tal sentido, puede afirmarse que el Tribunal de Justicia ha "descubierto" dichos principios a partir de los objetivos que llevaron a la creación de las comunidades europeas y, por ende, si bien no han sido contemplados expresamente en los tratados, sí responden a la intención de los Estados fundadores de ellas ${ }^{69}$.

\section{Tribunal Europeo de Derechos Humanos y Tribunal de Justicia de la Unión Europea (TJUE)}

El margen de apreciación ha sido un principio especialmente desarrollado y aplicado en el ámbito del Derecho Internacional. En el ámbito europeo, tanto la jurisprudencia del Tribunal Europeo de Derechos Humanos como la doctrina han

que, a pesar de todas las críticas que durante el siglo XX se han formulado al consensualismo o voluntarismo en la doctrina internacionalista (los Estados no se obligan sino en la medida de su propia voluntad), en el lenguaje moral o de valores que se esconde tras el discurso de los derechos radica un importante argumento en favor del consentimiento expresado en los instrumentos internacionales. Dicho de otro modo, lo no explicitado es, muchas veces, la condición para que un Estado suscriba un instrumento. Aspectos críticos, tales como la eutanasia, el aborto, la pena de muerte, la constitución de la familia, la configuración del matrimonio o la objeción de conciencia, entre tantos otros, permanecen en el dominio de la legislación constitucional o subconstitucional interna. En consecuencia, pretender que el tratado dice algo allí donde guarda silencio es tan grave como subvertir el significado de sus palabras". Ibíd.

67 Sentencias Costa/Enel, asunto 6/64 (1964): 15 de julio de 1964; Administration des finances de l'Etat/ Société anonyme Simmenthal, asunto 106/77 (1978): 9 de marzo de 1978. Ambas pueden consultarse en Pereira Menaut, A.C.; Bronfman, Alan; Cancela Outeda, Celso, y Hakansson, Carlos: La Constitución europea. Tratados constitutivos y jurisprudencia (Santiago de Compostela, U. de Santiago de Compostela) (2000).

68 Sentencia N.V. Algemene Transport - en Expeditie Onderneming Van Gend \& Loos/Administration Fiscale Néerlandaise, asunto 26/62 (1963): 5 de febrero de 1963. La sentencia puede consultarse en PereirA Menaut, A.C.; Bronfman, Alan; Cancela Outeda, Celso, y Hakansson, Carlos: La Constitución europea. Tratados constitutivos y jurisprudencia (Santiago de Compostela, U. de Santiago de Compostela) (2000).

${ }^{69}$ Sobre el origen y objetivos de las comunidades europeas, ver MARTínez EstaY, José Ignacio (2007): Introducción al Derecho y a las Instituciones de la Unión Europea (Santiago, Editorial Jurídica de Chile) Capítulo I. 
desarrollado ampliamente el margen de apreciación, como criterio que permite asegurar el respeto a las legítimas diferencias en las tradiciones y culturas de los países $^{70}$. El margen de apreciación nacional se transforma así en un mecanismo que hace posible la concreción del denominado principio de subsidiariedad, que, en palabras de Gerards, se traduce en que corresponde primeramente a los Estados asegurar el respeto de los derechos protegidos en la Convención, y que el Tribunal sólo puede actuar si aquéllos no han tenido éxito.

Asimismo, se ha entendido que el Tribunal no puede sustituir la opinión de los legisladores nacionales, y que la adecuada protección de los derechos admite diversas opciones, y que por ende no es razonable asumir que sólo la que pueda determinar el Tribunal será la más conveniente ${ }^{71}$. Por último, se ha señalado que todo ello permite garantizar de mejor forma las diferentes tradiciones y percepciones nacionales y culturales. En tal sentido "esta doctrina constituye un importante instrumento mediante el cual la Corte Europea de Derechos Humanos desempeña su complejo rol de tribunal internacional de derechos humanos" y le permite atender adecuadamente "a las sensibilidades y diferencias nacionales". Más aún, la doctrina del margen de apreciación "es una herramienta útil y flexible para determinar la intensidad del control sobre las interferencias en los derechos fundamentales"72.

En consideración a lo anterior, el Tribunal Europeo de Derechos Humanos ha sostenido que si bien los Estados Parte del Convenio Europeo de Derechos Humanos deben respetar los derechos allí reconocidos, existe un margen de apreciación para la interpretación de éstos, así como para determinar la forma de ampararlos ${ }^{73}$. En tal sentido, la intensidad del control dependerá de los siguientes factores:

- La existencia o no de un consenso respecto de la medida objeto de control. Muchas veces el Tribunal toma en cuenta si hay o no un consenso general en el

\footnotetext{
70 Gerards (2011), p. 104.

${ }^{71}$ Ibid.

72 Gerards (2011), pp. 102 y 104 (la traducción es mía). No obstante, en el ámbito de la Convención Europea de Derechos Humanos se alzan voces como la de García Roca, quien llama la atención sobre los riesgos que envuelve este principio, fundamentalmente por la amplia discrecionalidad que alberga. A su juicio, su uso conlleva sensación de inseguridad jurídica y falta de previsibilidad, aunque reconoce la necesidad de su reconocimiento como consecuencia del principio de subsidiariedad y de la existencia de sistema democráticos en los países que forman parte del sistema. García (2010).

73 Ibid. Esta doctrina ha sido sostenida por el Tribunal, por ejemplo, en los casos Naus contra Polonia, TEDH $2008 \backslash 57$ (2008): 16 septiembre 2008, y Rizhamadze contra Georgia, TEDH $2007 \backslash 50$ (2007): 31 julio 2007.
} 
Consejo de Europa sobre el tema materia del juicio. Cuando el Tribunal usa este criterio deja un amplio margen de apreciación si no existe consenso entre los Estados europeos o si el que hay es muy bajo ${ }^{74}$.

- El argumento de la mejor posición. En otras ocasiones, el Tribunal deja un amplio margen de apreciación a los Estados, porque entiende que están en una mejor posición para evaluar la razonabilidad de la necesidad o conveniencia de una limitación de los derechos fundamentales. Este sistema es utilizado por el Tribunal respecto de medidas que requieren complejas evaluaciones sociales o económicas, o que resultan particularmente delicadas o difíciles, lo que aconseja que sean los órganos nacionales quienes hagan los análisis y adopten las medidas que consideren más acordes. El Tribunal ha adoptado este criterio, por ejemplo, en materia de políticas de prevención en salud o de desastres ambientales y en el ámbito de las políticas de inmigración. Pero también lo ha usado en materias de trasfondo moral, en las que no hay consenso ${ }^{75}$.

- Importancia del derecho afectado. En determinados casos el Tribunal Europeo ha atenuado el margen de apreciación en atención a si la medida afecta la esencia o núcleo esencial de un derecho. El Tribunal ha entendido que subyacen a la Convención Europea de Derechos Humanos dos conceptos principales, a saber: el mantenimiento y promoción de los ideales y valores de una sociedad democrática, y la dignidad y libertad humanas. Estos criterios han sido usados fundamentalmente en casos sobre libertad de expresión y de libertad de reunión, así como en el respeto a las minorías. En este mismo sentido, el Tribunal ha sostenido que las medidas que afectan a la intimidad, como por ejemplo las relativas a la sexualidad o a la identidad, deben ser analizadas cuidadosamente ${ }^{76}$.

Por su parte, en el ámbito de la Unión Europea se ha reconocido el margen de apreciación de las autoridades nacionales respecto del Derecho de la Unión. Y así por ejemplo, en el caso Échirrolles (año 2000), el Tribunal de Justicia de la UE reconoció competencia a las autoridades nacionales "para evaluar las condiciones que permiten la aplicación de un principio general" 77 . Y en el caso Haim (año 2000), el mismo Tribunal aplicó el margen de apreciación para determinar

\footnotetext{
${ }^{74}$ Gerards (2011), p. 108.

75 Ibid., pp. 110-111.

${ }^{76}$ Ibid., p. 113.

77 NúNEZ (2012), p. 10.
} 
la responsabilidad estatal en la infracción del Derecho de la Unión ${ }^{78}$, y también ha sido aplicado para validar medidas de restricción a libertades comunitarias por parte de los Estados Parte de la Unión, como en los casos Ferring (año 2000), Henn (1979), Darby (1979), Karner (2004), Sirdar (1999), Omega (2004) y Schmidberger ${ }^{79}$.

\section{Corte Interamericana de Derechos Humanos (CIDH)}

A diferencia de Europa, en el sistema interamericano de derechos humanos el principio de subsidiariedad, que es la fuente del margen de apreciación nacional, se muestra como una consecuencia directa de algunos preceptos de la Convención Americana de Derechos Humanos. El primero de ellos es el artículo 1.1, según el cual los Estados son los principales responsables de respetar y garantizar los derechos ${ }^{80}$. El segundo es el artículo 25, que involucra el deber de los Estados Parte de contar con recursos judiciales que permitan dar tutelas a los derechos de las personas ${ }^{81}$. Por último, el principio de subsidiariedad está también tácitamente reconocido en el artículo 46.1.a) de la Convención Americana de Derechos Humanos, que contempla, como requisito previo para acudir a la Comisión, haber agotado las vías judiciales internas ${ }^{82}$.

78 Ibid.

79 Ibid., pp. 10-11.

80 Según este artículo: "Los Estados Parte en esta Convención se comprometen a respetar los derechos y libertades reconocidos en ella y a garantizar su libre y pleno ejercicio a toda persona que esté sujeta a su jurisdicción, sin discriminación alguna por motivos de raza, color, sexo, idioma, religión, opiniones políticas o de cualquier otra índole, origen nacional o social, posición económica, nacimiento o cualquier otra condición social".

${ }^{81}$ De acuerdo a este artículo: "1. Toda persona tiene derecho a un recurso sencillo y rápido o a cualquier otro recurso efectivo ante los jueces o tribunales competentes, que la ampare contra actos que violen sus derechos fundamentales reconocidos por la Constitución, la ley o la presente Convención, aun cuando tal violación sea cometida por personas que actúen en ejercicio de sus funciones oficiales.

2. Los Estados Parte se comprometen:

a) a garantizar que la autoridad competente prevista por el sistema legal del Estado decidirá sobre los derechos de toda persona que interponga tal recurso.

b) a desarrollar las posibilidades de recurso judicial, y

c) a garantizar el cumplimiento, por las autoridades competentes, de toda decisión en que se haya estimado procedente el recurso".

82 Esta norma dispone que: "1. Para que una petición o comunicación presentada conforme a los artículos 44 o 45 sea admitida por la Comisión, se requerirá:

a) que se hayan interpuesto y agotado los recursos de jurisdicción interna, conforme a los principios del Derecho Internacional generalmente reconocidos;". 
La CIDH ha acudido también al margen de apreciación nacional, como criterio que permite asegurar el respeto a diferencias legítimas en la manera de amparar y proteger derechos por parte de los Estados Parte de la Convención. Así, en la Opinión Consultiva OC 4/84, sobre propuesta de modificación a la Constitución Política de Costa Rica (19 de enero de 1984, Serie A No 4), la CIDH reconoció margen de apreciación para que los Estados regulen la adquisición de la nacionalidad. A su vez, en Herrera Ulloa vs. Costa Rica (2 de julio de 2004, Serie C No 107), la CIDH concedió margen de apreciación para que los Estados fijen recursos ordinarios eficaces para proteger los derechos. Y más recientemente, en el caso Penitenciarías de Mendoza (resolución de medidas provisionales de 1 de julio de 2011), sostuvo que, en virtud del principio de subsidiariedad, los Estados pueden determinar la forma de mejorar las condiciones penitenciarias.

\section{BREVE REFERENCIA AL CONCEPTO DE AUTO-RESTRICCIÓN, DEFERENCIA RAZONADA Y MARGEN DE APRECIACIÓN EN EL \\ Tribunal Constitucional CHILENO}

Los mismos desafíos que entraña el control judicial en otros sistemas jurídicos son también replicables en Chile. Más aún, a contar de la reforma constitucional de 2005, éstos aparecen con más claridad, debido al reforzamiento de las competencias del Tribunal Constitucional. Al respecto Zapata sostiene que a partir de dicha reforma este principio "se ha transformado en un elemento central de su actividad jurisdiccional", a través del cual refleja su "reticencia a incursionar en el examen de aspectos de mérito y oportunidad o como disposición a preferir, en caso de duda, aquella interpretación de la ley que resulta compatible con la Constitución" 83 .

Sin embargo, ya antes de la reforma el Tribunal había comenzado la aplicación de la deferencia hacia el legislador, por ejemplo en las sentencias Roles $\mathrm{No}^{\circ} .43$, $67,141,231,257,271,293,297,309$ y 334 . El criterio de deferencia utilizado en la mayoría de éstas fue el de "interpretación conforme" (sentencias Roles Nos. 43, 67, 257, 271, 293, 297, 309 y 334). De acuerdo a éste, entre distintas interpretaciones posibles de una norma, debe preferirse aquella que sea más acorde a la Constitución.

Con posterioridad a la entrada en vigor de la referida reforma constitucional, el Tribunal ha continuado dando aplicación al referido principio, extendido también

83 ZAPATA (2008), p. 231. 
a las actuaciones judiciales, a raíz de su competencia para conocer de cuestiones de inaplicabilidad. En concreto, el Tribunal ha aclarado que no le corresponde sustituir al juez ordinario en la resolución del asunto que da origen a la cuestión de inaplicabilidad y que sólo toca a éste decidir sobre la controversia propia de cada juicio. A modo de ejemplo pueden citarse las sentencias Roles $\mathrm{No}_{\mathrm{s}}$. 481, 503, 522, 626, 706, 790, 1001, 1129, 1250, 1266, 1340, 1348, 1361, 1463, 1678, 1683, 1710, 201484, 2025, 2111, 2292 у 2386.

En términos generales, puede concluirse que el Tribunal lo entiende como una consecuencia de la separación de poderes, y más precisamente, como un doble deber. Por una parte, como deber de respeto que se deben entre sí los poderes públicos y, por otra, como deber de respeto a las decisiones adoptadas por cada uno de ellos en el ámbito de sus competencias. Ello ha quedado claramente resumido en la sentencia Rol No 309, en la que el Tribunal señala con claridad que "este principio tiene muchos fundamentos, pero por ahora, cabe sólo señalar dos: la separación de poderes y el recíproco respeto que los distintos órganos del Estado se deben entre sî" (considerando 2).

Zapata sostiene que de la jurisprudencia del Tribunal Constitucional se deducen el reconocimiento de dos elementos constitutivos de la auto-restricción o deferencia: la autonomía del legislador y la presunción de constitucionalidad de los actos del legislador, respectivamente ${ }^{85}$. La autonomía del legislador ha sido reconocida, por ejemplo, en las sentencias Roles Nos. 43, 67, 141, 231, 280, $334,815,1153,1217,1244,1337,1380,1445,1467$ y 1535 . Por su parte, la presunción de constitucionalidad ha sido recogida, por ejemplo, en las sentencias Roles Nos. 309, 626, 634, 1254, 1330 y $1710^{86}$.

\footnotetext{
${ }^{84}$ En esta sentencia el Tribunal Constitucional alude a la necesidad de que su actuar sea deferente con los jueces de fondo (considerando sexto).

85 ZapaTa (2008), pp. 233-247.

${ }^{86}$ Respecto de esta presunción de constitucionalidad, debe destacarse que durante la vigencia de la Constitución de 1925, el Tribunal Constitucional ya la había acogido en su sentencia Rol No 1 de 1971, en la prevención del ministro Sr. Jacobo Schaulsohn Numhauser, quien señaló que "es natural la inclinación a esperar que los poderes o representantes populares no se vean impulsados a recurrir a este Tribunal, tanto más que el sistema democrático representativo, con su clásica división de poderes públicos independientes e interdependientes a la vez, descansa sobre la base de la armonía y equilibrio y en su funcionamiento; pero, y aun cuando por la jerarquía representativa de los Poderes que emiten un pronunciamiento, están lógicamente amparados por una presunción de constitucionalidad, no es menos cierto que requerido este Tribunal queda en la necesidad ineludible de juzgar con estricto y riguroso apego a las normas constitucionales que se encuentren en juego" (el destacado es mío).
} 
Pero junto a todo lo anterior, es interesante constatar que en varias de sus sentencias el Tribunal Constitucional utiliza otro concepto a la hora de controlar la actuación del legislador, a saber: el "margen de apreciación”. Así sucede, por ejemplo, en las sentencias Roles $\mathrm{No}^{\circ}$. 821, 1481, 1399, 1564, 1518, 1683. En opinión del Tribunal, el margen de apreciación tiene dos significados. En primer lugar implica "...la opción de política legislativa que corresponde al legislador decidir...", y en segundo lugar supone la imposibilidad de que el Tribunal entre "a calificar la bondad de las disposiciones legales o administrativas" (Rol No 821, considerandos 13 y 16 ).

\section{CONSIDERACIONES FINALES}

Como se desprende de lo señalado a lo largo de este trabajo, la idea de autorestricción y de deferencia es una consecuencia clara del principio de separación de poderes. Se refiere a la actitud de respeto que deben observar entre sí los diversos órganos que ejercen potestades públicas, lo que conlleva reconocerse mutuamente las competencias que corresponden a cada uno de ellos y las limitaciones derivadas de esto.

Desde el punto de vista del control judicial de la actuación de los poderes públicos, la forma en que se concreta esa deferencia es a través de diversos principios o criterios. Así, el análisis comparado y nacional permite advertir un general reconocimiento a la autonomía del legislador y, en su caso, de la Administración. Del mismo modo, por regla general se parte del supuesto de que las normas objeto de control no son contrarias a la Constitución, lo que implica una presunción de licitud de aquéllas.

Junto a aquello surge también un criterio que complementa los anteriores, a saber: el margen de apreciación que tienen los poderes públicos para ejercer sus facultades discrecionales. Este criterio no sólo se aplica respecto del control judicial de los actos de dichos poderes, sino que también encuentra un espacio en el ámbito del control de la actuación de los Estados en los sistemas jurídicos supranacionales.

En lo que respecta a nuestro país, el Tribunal Constitucional ha aplicado la deferencia tanto respecto del legislador, del Ejecutivo como de los jueces ordinarios. En el caso del legislador, ello se ve reforzado por el reconocimiento de su autonomía y de la presunción de legitimidad de la ley y por la aplicación del criterio de interpretación conforme. Tratándose de la deferencia al juez, el Tribunal ha tenido buen cuidado de aclarar que, en materia de inaplicabilidad, su competencia limita con la autonomía del juez ordinario para resolver conforme a Derecho el asunto en que se originó la cuestión. 
Asimismo, el Tribunal Constitucional utiliza el concepto de margen de apreciación para el control de la potestad discrecional del legislador y del Ejecutivo, lo que lo lleva a no controlar el mérito de las actuaciones discrecionales. Del mismo modo, el Tribunal ha reconocido un cierto margen de autonomía del Ejecutivo con relación a las funciones de gobierno y de administración, obviamente dentro de los márgenes contemplados en la Constitución. Finalmente, el Tribunal Constitucional ha utilizado también como mecanismo de deferencia la presunción de legalidad y, en último término, de juridicidad de los actos administrativos, que al menos en Chile está expresamente prescrita en los artículos $3^{\circ}$ inciso 8 y 51 de la Ley No 19.880 sobre Procedimientos Administrativos, respectivamente ${ }^{87}$.

\section{Bibliografía CitadA}

Aldunate Lizana, Eduardo (2009): Jurisprudencia constitucional 2006-2009. Estudio selectivo, Santiago, LegalPublishing.

Aragón Reyes, Manuel (1999): Constitución y control del poder, Bogotá, Universidad Externado de Colombia.

Cançado Trindade, Antônio Augusto (2001): El Derecho internacional de los derechos humanos en el siglo XXI (Santiago, Editorial Jurídica de Chile, segunda edición).

EduIn, Douglas E. (2010): Judges and unjust law (Michigan, The University of Michigan Press).

Favoreau, Louis y Philip, Loïc (1991): Les grandes décisions du Conseil Constitutionnel. (Paris, Sirey).

FerRajoli, Luigi (2008): Democracia y garantismo, Madrid, Trotta.

Forsyth, Christopher (editor) (2000): Judicial review \& the Constitution, Londres, Hart.

GARCIA ROCA, Javier (2010): El margen de apreciación nacional en la interpretación del Convenio Europeo de Derechos Humanos: soberanía e integración (Madrid, Civitas/Thomson Reuters).

GERARDS, Janneke (2011): "Pluralism, Deference and the Margin of Appreciation Doctrine”, en European Law Journal, Vol. 17, pp. 80-120.

Goesel-Le Bihan, Valérie (2009): "France", en Annuaire international de justice constitutionnel: Le juge constitutionnel et la proportionnalité(Vol. XXV), 191-212.

${ }^{87}$ Ello sin perjuicio de que un importante sector de la doctrina chilena pone en duda la constitucionalidad de estas normas. Vid. Soto Kloss (2012), p. 337. 
Goldstone, Lawrence (2008): “The activist. John Marshall, Marbury v. Madison”. (New York, Walker \& Company).

Hamilton, A.; Madison, J., y Jay, J. (1943): El federalista, México (Fondo de Cultura Económica).

HaAs, Evelyn (2010): TCF Federal: "Juridificación de la política-politización de la justicia”, en Estudios Constitucionales año 8, No 1, pp. 367-378.

Hormazábal Malarée, Hernán (2006): El nuevo Tribunal Constitucional. Los derechos fundamentales y el moderno recurso de inaplicabilidad, Santiago, LexisNexis.

Jacobs, Francis G., y White, Robin C.A. (1996): The European Convention on Human Rights, Oxford, (Clarendon Press).

Kelly, Harbison y Belz (1983): The American Constitution. Its Origins and Development. (New York, W.W. Norton \& Company).

KOMMERs, Donald P. (1997): The constitutional jurisprudence of the Federal Republic of Germany (Durham, Duke University Press).

Laubadére, André, Venezia, Jean-Claude y Gaudemet, Jean-Claude (1990): Traité de Droit Administratif. (Paris, L.G.D.J.).

Loewenstein, Karl (1976): Teoría de la Constitución. (Barcelona, Ariel).

MalTz, Earl M. (1994): Rethinking constitutional law. (Kansas, University Press of Kansas).

MarTínez Estay, José Ignacio (2007): Introducción al Derecho y a las Instituciones de la Unión Europea, Santiago, Editorial Jurídica de Chile.

(2009): "Constitución y fuentes del Derecho", en Arancibia Mattar, Jaime y Martínez Estay, José Ignacio, La primacía de la persona. Estudios en Homenaje al profesor Eduardo Soto Kloss. (Santiago, LegalPublishing/AbeledoPerrot).

Montesquieu (1998): Del espiritu de las leyes (Madrid, Tecnos).

Núñez Poblete, Manuel (2009): "La función del derecho internacional de los derechos de la persona”, Revista de Derecho de la Pontificia Universidad Católica de Valparaiso XXXII, pp. 487-529.

(2012): "Sobre la doctrina del margen de apreciación nacional. La experiencia latinoamericana confrontada y el thelos constitucional de una técnica de adjudicación del derecho internacional de los derechos humanos", en ACOsTA Alvarado, Paola Andrea y Núñez Poblete, Manuel (coord.). (2009): El margen de apreciación en el Sistema Interamericano de Derechos Humanos: Proyecciones Regionales y Nacionales. (México, Universidad Nacional Autónoma de México, Instituto de Investigaciones Jurídicas), pp. 3-49. 
Pereira Menaut, Antonio Carlos (1992): El ejemplo constitucional de Inglaterra. (Madrid, Facultad de Derecho de la Universidad Complutense). (2006): Teoría Constitucional. (Santiago, LexisNexis).

Pereira Menaut, A.C.; Bronfman, Alan; Cancela Outeda, Celso, y HaKansson, Carlos (2000): La Constitución europea. Tratados constitutivos y jurisprudencia. (Santiago de Compostela, U. de Santiago de Compostela).

Rivero, Jean y Waline, Jean (1992): Droit Administratif. (Paris, Dalloz).

SchneIder, Hans Peter (1991): Democracia y Constitución. (Madrid, Centro de Estudios Constitucionales).

Soто Kloss, Eduardo (2012): Derecho Administrativo. Temas fundamentales. (Santiago, AbeledoPerrot).

STITH, Richard (2005): "Imperio del Derecho versus imperio de los jueces: un alegato por el pluralismo jurídico", en Revista de Derecho, Universidad Católica del Norte, año 12, No 1, pp. 157-182.

(2008): "Securing the Rule of Law trough interpretative pluralism: an argument from comparative Law", en Hastings Constitutional Law Quarterly, Vol. 35, No 3, pp. 401-447.

STONE SweET, Alec (2000): Governing with judges. Constitutional politics in Europe. (Oxford, Oxford University Press).

Sutherland, Arthur E. (1972): De la Carta Magna a la Constitución Norteamericana. (Buenos Aires, TEA).

WheAre, K.C. (1975): Las constituciones modernas. (Barcelona, Labor).

Zapata LaRraín, Patricio (2008): Justicia constitucional. Teoría y práctica en el derecho chileno y comparado. (Santiago, Editorial Jurídica de Chile).

ZúÑIga Urbina, Francisco (2010): Acciones de inaplicabilidad e inconstitucionalidad. Doctrina y jurisprudencia del Tribunal Constitucional sobre temas procesales. (Santiago, AbeledoPerrot).

\section{JURISPRUDENCIA CITADA}

Tribunales extranjeros e internacionales

Arrêt Gomel (1914), Conseil d'Etat, France.

Arrêt Lagrange (1961), Conseil d'Etat, France.

Associated Provincial Picture Houses v. Wednesbury Corporation (1948), Court of Appeal, England and Wales. 
Decisión 86-218 DC, de 18 de noviembre de 1986, Conseil Constitutionnel, France, en http://www.conseil-constitutionnel.fr/conseil-constitutionnel/ francais/les-decisions/acces-par-date/decisions-depuis-1959/1986/86-218-dc/ decision-n-86-218-dc-du-18-novembre-1986.8291.html.

Marbury v. Madison (1803), Supreme Court, United States of America.

Costa/Enel, asunto 6/64 (1964), de 15 de julio de 1964, Tribunal de Justicia de la Comunidad Europea.

Administration des finances de l'Etat/Société anonyme Simmenthal (1978), asunto 106/77, 9 de marzo de 1978, Tribunal de Justicia de la Comunidad Europea. N.V. Algemene Transport - en Expeditie Onderneming Van Gend \& Loos/Administration Fiscale Néerlandaise, asunto 26/62 (1963), 5 de febrero de 1963, Tribunal de Justicia de la Comunidad Europea.

Regina/Maurice Henn y John Frederick Darby (1979), asunto C-34/79, 14 de diciembre de 1979, Tribunal de Justicia de la Comunidad Europea.

Angela M. Sirdar v. The Army Board and Secretary of State for Defence (1999), asunto C-273/97, 26 de octubre de 1999, Tribunal de Justicia de la Comunidad Europea.

Ferring Arznermittel GmbH v. Eurim-Pharm Arznermittel GmbH (2002), asunto C-172/00, 10 de septiembre, Tribunal de Justicia de la Comunidad Europea. Herbert Karner Industrie-Auktionen GmbH v. Toost Wijk GmbH (2004), asunto C-71/02, 25 de marzo de 2004, Tribunal de Justicia de la Comunidad Europea. Omega Spielhallen - und Automatenaufstellungs - GmbH v. Oberbürgermeisterin der Bundesstadt Bonn (2004), asunto C-36/02, 4 de febrero de 2004, Tribunal de Justicia de la Comunidad Europea.

Eugen Schmidberger, Internationale Transporte und Planzüge v. Austria (2003), asunto C-112/00, 12 de junio de 2003.

Paises Bajos v. Parlamento Europeo y Consejo de la Unión Europea (2001), asunto C-377/98, 9 de octubre de 2001.

Rizhamadze contra Georgia, Tribunal Europeo de Derechos Humanos $2007 \backslash 50$ (2007), 31 julio 2007.

Naus contra Polonia, Tribunal Europeo de Derechos Humanos 2008157 (2008), de 16 septiembre 2008.

Opinión Consultiva OC 4/84, sobre propuesta de modificación a la Constitución Política de Costa Rica (19 de enero de 1984, Serie A, No 4), Corte Interamericana de Derechos Humanos. 
Herrera Ulloa vs. Costa Rica (2 de julio de 2004, Serie C No 107), Corte Interamericana de Derechos Humanos.

Penitenciarías de Mendoza (Resolución de medidas provisionales de 1 de julio de 2011), Corte Interamericana de Derechos Humanos.

\section{Tribunal Constitucional de Chile}

Sentencias roles:

43, de 24 de febrero de 1987, proyecto de Ley Orgánica Constitucional de los Partidos Políticos.

67, de 14 de marzo de 1989, Control de constitucionalidad respecto del proyecto de ley que modifica las Leyes Orgánicas constitucionales $\mathrm{No}^{\circ}$. 18.603 y 18.700, relativas a los partidos políticos y a la Ley sobre Votaciones Populares y Escrutinios.

141, de 21 de enero de 1992, Requerimiento respecto de las cuestiones de constitucionalidad suscitadas durante la tramitación del proyecto que modifica la Ley Orgánica Constitucional de Municipalidades No 18.695, de 3 de marzo de 1988.

231, de 2 de febrero de 1996, Requerimiento de senadores respecto del Decreto con Fuerza de Ley No 192, dictado con fecha 30 de noviembre de 1995, del Ministerio del Trabajo y Previsión Social, Subsecretaría de Previsión Social, publicado en el Diario Oficial de fecha 5 de enero de 1996.

249, de 9 de octubre de 1996, Requerimiento de Diputados respecto del proyecto de ley que autoriza el incremento hasta la cantidad de \$ 3.085 millones, transfiriendo tales recursos, por medio de la modificación de la glosa No 13 del Presupuesto Nacional vigente, para absorber las mayores pérdidas operacionales de la Empresa Nacional del Carbón S.A.

257, de 19 de agosto de 1997, Control de constitucionalidad respecto del proyecto de ley que fija el nuevo Estatuto de Capacitación y Empleo.

271, de 6 de marzo de 1998, Control de constitucionalidad respecto del proyecto de ley que modifica el Decreto Ley No 701, de 1974, sobre Fomento Forestal.

280, de 16 de septiembre de 1998, Requerimiento de diputados acerca del proyecto de ley que rebaja la tasa de los aranceles a las importaciones e introduce modificaciones a otras normas tributarias y económicas.

293, de 8 de septiembre de 1999, Control de constitucionalidad respecto del proyecto de ley que establece la Ley Orgánica Constitucional del Ministerio Público. 
297, de 18 de octubre de 1999, Control de constitucionalidad respecto del proyecto de ley que concede beneficios económicos al personal del Servicio de Impuestos Internos, del Consejo de Defensa del Estado, de la Dirección de Presupuestos y de las Fuerzas Armadas y contiene otras normas sobre racionalización del sector Hacienda.

309, de 7 de julio de 2000, Requerimiento presentado por un grupo de señores diputados, que representan más de la cuarta parte de los miembros en ejercicio de la Cámara, respecto de la inconstitucionalidad del Convenio No 169 , sobre Pueblos Indígenas y Tribales en Países Independientes, adoptado por la Organización Internacional del Trabajo el 27 de junio de 1989.

334 , de 23 de julio de 2001, Requerimiento respecto del proyecto de ley que modifica el Decreto Ley No 3.500, de 1980, que establece normas relativas al otorgamiento de pensiones a través de la modalidad de rentas vitalicias.

481, de 13 de abril de 2006, Requerimiento de inaplicabilidad por inconstitucionalidad de Inversiones Errázuriz Ltda., respecto de los preceptos legales que señala, en la causa 2349-2005 de la Corte Suprema.

503, de 16 de mayo de 2006, Requerimiento de inaplicabilidad por inconstitucionalidad de Sociedad Agrícola Relbún Limitada y de Inmobiliaria Hacienda Chacabuco S.A. respecto del artículo 147 bis del Código de Aguas, en relación con los autos Rol No 8.547-2005 sobre recurso de reclamación interpuesto ante la Corte de Apelaciones de Santiago.

522, de 7 de julio de 2006, Requerimiento de inaplicabilidad por inconstitucionalidad de Lino Díaz Ramos, Walter Lund Bellocchio, Jaime Cortés Arcos, Raúl Farfán Carmona y Pedro Sabat Pietro Caprina, respecto del artículo 43, Nos. $1^{\circ}$ y $2^{\circ}$, de la Ley de Quiebras, en la causa Rol No 9.145-2003, del Séptimo Juzgado Civil de Santiago.

626, de 20 de octubre de 2006, Requerimiento de inaplicabilidad por inconstitucionalidad de José Alberto Izquierdo Artigas respecto de la expresión "del acta de mensura” contenida en el inciso primero del artículo 243, del Código de Minería, en los autos Rol No116-05 de la Corte Suprema.

634, de 17 de octubre de 2006, Requerimiento de inaplicabilidad respecto del artículo 13 de la Ley No 18.575, presentado por la Corte de Apelaciones de Valparaíso en la causa caratulada "Lean Casas Cordero, Carlos Éric con Director Nacional de Aduanas", Rol No 2336-06, seguida ante ese mismo Tribunal.

706, de 10 de enero de 2007, Requerimiento de inaplicabilidad por inconstitucionalidad de Labbe y Compañía Ltda. respecto de los artículos 10 de la 
Ley No 18.772, 20 del D.L. No 2.186 y del Decreto No 783, de 2006, del Ministerio de Obras Públicas.

790, de 25 de mayo de 2007, Requerimiento de inaplicabilidad presentado por Fernando Coloma Reyes y otros respecto del artículo $4^{\circ}$ de la Ley No 18.549 y del artículo 29 de la Ley No 18.669 en la causa caratulada "Lagos, Hipólito y otros con INP”, Rol No 18.828-06, seguida ante el 7o Juzgado Civil de Santiago.

815, de 10 de julio de 2008, Requerimiento de inaplicabilidad presentado por Patricio Rodrigo Meneses Farías respecto del artículo 230, inciso primero, del Código Procesal Penal, en la causa RIT No 179-2005, RUC No 0510001570 08, del Juzgado de Garantía de San Fernando.

1001, de 26 de septiembre de 2007, Proyecto de Ley que modifica el Código Penal y el Código Procesal Penal en materias de seguridad ciudadana y refuerza las atribuciones preventivas de las policías (Boletín No 4321-07).

1129, de 20 de mayo de 2008, Requerimiento de inaplicabilidad deducido por Waldo Rojas Soto, Micael Goldschmidt Isaak, Fernando Mura Álvarez y Sergio Rojas Abarzúa, en su calidad de miembros de la Comisión Liquidadora de la sociedad Promepart S.A., respecto del artículo 465 del Código del Trabajo en relación a la causa de la Corte de Apelaciones de Santiago, Rol No 2168-2008.

1153, de 23 de junio de 2008, Requerimiento de inconstitucionalidad presentado por 16 senadores respecto de los Decretos Supremos Nos. 45 y 46, de 16 y 20 de mayo de 2008, respectivamente, del Ministerio de Transportes y Telecomunicaciones, y Decreto Supremo No 583, de 21 de abril de 2008, del Ministerio de Hacienda.

1217, de 26 de agosto de 2008, Requerimiento de inaplicabilidad de José Tomás Rojas Rivera respecto del artículo 104 de la Ley General de Bancos, en causa Rol No 02-2007, seguida en el Primer Juzgado de Letras de Curicó, caratulada "Corpbanca con Rojas Rivera, José Tomás".

1244, de 3 de octubre de 2008, Requerimiento de inaplicabilidad por inconstitucionalidad de Cosmética Vegetal S.A. respecto de los artículos 230 inciso primero y 237 inciso antepenúltimo en causa RUC No 0710010844-K y RIT No 4428-2007 del 4o Juzgado de Garantía de Santiago.

1250 , de 8 de octubre de 2008, Requerimiento de inaplicabilidad por inconstitucionalidad de Renato Ananías Chenevey respecto del inciso primero del artículo 548 del Código de Procedimiento Penal, en la causa Rol No 79.920-PL y acumuladas, del $2^{\circ}$ Juzgado del Crimen de San Miguel -en la actualidad $8^{\circ}$ Juzgado-, y actualmente ante la Corte Suprema bajo el Rol No 4455-2008. 
1254, de 15 de octubre de 2008, Requerimiento de inconstitucionalidad del Presidente del Colegio de Abogados de Chile A.G., señor Enrique Barros Bourie, en representación de dicha entidad respecto del texto íntegro del artículo 595 del Código Orgánico de Tribunales. En subsidio de lo anterior, solicita se declare la inconstitucionalidad del inciso primero del mismo artículo y, en subsidio de esto último, se declare inconstitucional la expresión "gratuitamente", contenida en la misma norma legal.

1266, de 29 de octubre de 2008, Requerimiento de inaplicabilidad de Bernardo Salvi Fernández respecto del No 8 del artículo 33 bis de la Ley No 18.933 en causa Rol de ingreso No 6590-2008, caratulada "Salvi Fernández, Bernardo, con Isapre Banmédica S.A.” de la Corte de Apelaciones de Santiago.

1330, de 16 de febrero de 2009, Requerimiento de inaplicabilidad por inconstitucionalidad de Carolain Margaret Ulloa Quezada respecto del artículo 38 ter de la Ley No 18.933, en Rol No 558-2009 de la Corte de Apelaciones de Santiago.

1337, de 25 de febrero de 2009, Requerimiento de inaplicabilidad de Raúl Antonio Arriagada Gutiérrez, respecto del artículo 230 del Código Procesal Penal, en proceso penal RIT 1997-2007 y RUC 0710007486-3, del Juzgado de Garantía de Graneros.

1340, de 4 de marzo de 2009, Requerimiento de inaplicabilidad del juez presidente del Juzgado de Familia de Pudahuel, en la causa RIT C-111-2009, caratulada "Muñoz con Muñoz", sobre la aplicación del artículo 206 del Código Civil.

1348, de 20 de marzo de 2009, Requerimiento de inaplicabilidad por inconstitucionalidad de Primera Sala de la Corte de Apelaciones de Talca respecto del artículo 38 ter de la Ley No 18.933, en Rol No 1537-2008, en recurso de protección de la Corte de Apelaciones de Talca.

1361, de 7 de abril de 2009, Requerimiento de 10 senadores de la República en contra de la constitucionalidad de determinados artículos del proyecto de ley que establece la Ley General de Educación (LEGE).

1380, de 5 de mayo de 2009, Requerimiento de inaplicabilidad de Carlos Jordán Ortiz respecto de los artículos 186 y 230 del Código Procesal Penal, en proceso RIT 8752-2008 y RUC 0800880916-0 del 8 Juzgado de Garantía de Santiago.

1445 , de 24 de julio de 2009, Requerimiento de inaplicabilidad por inconstitucionalidad de Eduardo Sánchez Eyquem respecto del artículo 230 inciso 
primero y artículos 231 y 237 inciso primero, segundo, tercero letra a), cuarto quinto, séptimo y octavo, y artículo 240 inciso segundo del Código Procesal Penal, en RUC 09000447112-9, RIT 6118-2009 del 4º Juzgado de Garantía de Santiago.

1463, de 18 de agosto de 2009, Requerimiento de inaplicabilidad por inconstitucionalidad de Gerard Philippe Bordachar Sotomayor y Otros, respecto del artículo 2331 del Código Civil, en ingreso No 2.517-2008, en recurso de protección de la Corte de Apelaciones de Santiago, y en Rol de Ingreso 5.034-2005 del $18^{\circ}$ Juzgado Civil de Santiago.

1467, de 21 de agosto de 2009, Requerimiento de inaplicabilidad por inconstitucionalidad de Arturo Oyarzún Godoy respecto del artículo 230 del Código Procesal Penal, en RIT 471-2008, en RUC 0810001973-7 del Tercer Juzgado de Garantía de Santiago.

1535, de 12 de noviembre de 2009, Requerimiento de inaplicabilidad por inconstitucionalidad de María Rocío Zamorano Pérez, respecto del artículo 277 del Código Procesal Penal, en RUC No 080100636-9 y RIT 8867-2008 del 8º Juzgado de Garantía de Santiago.

1678, de 7 de abril de 2010, Acción de inaplicabilidad por inconstitucionalidad de Alberto Michel Haddad Valech, respecto del artículo 212 del Código Civil, en los autos Rol No 3678-2010 sobre recursos de casación en la forma y en el fondo interpuestos en contra de la sentencia de segunda instancia dictada por la Corte de Apelaciones de Santiago.

1683, de 13 de abril de 2010, Acción de inaplicabilidad por inconstitucionalidad de Jorge Washington Sepúlveda Álvarez respecto del artículo 365 del Código Penal, en los autos RUC 0800242317-1 y RIT 1287-2008 sustanciados ante el Juzgado de Garantía de Cañete.

1710, de 27 de abril de 2010, Proceso de inconstitucionalidad iniciado de oficio por el Tribunal Constitucional con relación al artículo 38 ter de la Ley No 18.933. 2014, de 9 de junio de 2011, Requerimiento de inaplicabilidad por inconstitucionalidad presentado por Luisa Carolina Naranjo Soto respecto del artículo 88 de la Ley No 16.744, en los autos RIT No O-496-2010, caratulados "Soto con Sociedad Comercial Clover S.A.”, sobre juicio de accidente del trabajo del que conoce el Juzgado de Letras del Trabajo de San Miguel. 